\title{
Correction to: Intraseasonal variation of the summer rainfall over the Southeastern United States
}

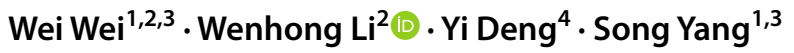

Published online: 1 September 2018

(c) The Author(s) 2018

\section{Correction to: Climate Dynamics \\ https://doi.org/10.1007/s00382-018-4345-6}

The HTML version of this article was published with incorrect copyright line. The correct copyright line is "The Author(s) 2018". This error has been corrected.
Open Access This article is distributed under the terms of the Creative Commons Attribution 4.0 International License (http://creativeco mmons.org/licenses/by/4.0/), which permits unrestricted use, distribution, and reproduction in any medium, provided you give appropriate credit to the original author(s) and the source, provide a link to the Creative Commons license, and indicate if changes were made.
The original article can be found online at https://doi.org/10.1007/ s00382-018-4345-6.

\section{Wenhong Li}

Wenhong.li@duke.edu

1 School of Atmospheric Sciences, Sun Yat-sen University, Guangzhou, China

2 Earth and Ocean Sciences, Nicholas School of the Environment, Duke University, Durham, NC 27708-0328, USA

3 Guangdong Province Key Laboratory for Climate Change and Natural Disaster Studies, Sun Yat-sen University, Guangzhou, China

4 School of Earth and Atmospheric Sciences, Georgia Institute of Technology, Atlanta, GA, USA 